http://jmscr.igmpublication.org/home/

ISSN (e)-2347-176x ISSN (p) 2455-0450

crossref DOI: https://dx.doi.org/10.18535/jmscr/v10i2.10

Journal Of Medical Science And Clinical Research

IGM Publication

An official Publication of IGM Publication

\title{
Nodular Syringocystadenoma Papilliferum Arising Within Nevus Sebaceous: A Rare Presentation over Scalp
}

\author{
Authors \\ Dr Shailja Chauhan ${ }^{1 *}$, Dr Vikant Verma ${ }^{2}$ \\ ${ }^{1} \mathrm{MD}$ (Dermatology, Venereology and Leprosy), Civil Hospital, Rampur Bushar, District- Shimla, \\ Himachal Pradesh \\ ${ }^{2}$ MD (Medicine), Civil Hospital, Rampur Bushar, District- Shimla, Himachal Pradesh \\ *Corresponding Author \\ Dr Shailja Chauhan
}

MD (Dermatology, Venereology and Leprosy), Civil Hospital, Rampur Bushar, District- Shimla, Himachal Pradesh

\section{Abstract}

Syringocystadenoma papilliferum (SP) is a rare benign hamartomatous adnexal tumour which originates from the apocrine or eccrine sweat glands. It is typically present over the head or neck region at birth and often enlarges at puberty. Approximately one-third of SP develops within nevus sebaceous. The nodular variety usually presents over the trunk however, in our case it presented over the scalp.

\section{Introduction}

Nevus sebaceous of Jadassohn (NS) is a cutaneous hamartoma with involvement of epidermis, pilosebaceous units and other adnexal structures. The most common site is the scalp, although there are reports in literature from other sites as well. It usually presents at an early age and has been known to be associated with several benign and malignant neoplasms with progressing age. ${ }^{1}$

Syringocystadenoma papilliferum (SP) is a rare benign hamartomatous adnexal tumour which originates from the apocrine or eccrine sweat glands. It is typically present over the head or neck region at birth and often enlarges at puberty. Approximately one-third of SP develops within nevus sebaceous. ${ }^{2}$ Three clinical types of Syringocystadenoma Papilliferum described are:

- Plaque type: The tumor presents as a patch of hair loss on the scalp and in one third of the individuals, is associated with nevus sebaceous of Jadassohn or may occur de novo.

- Linear type: Presents as multiple, firm, papules or nodules in groups, varying in size from $1-10 \mathrm{~mm}$ and are usually present on the face, head, and neck region.

- Solitary nodular type: This type presents as raised nodules up to $1 \mathrm{~cm}$ in size most commonly on the chest, back, shoulders, and axilla.

\section{Case Report}

A 27 year old female presented with single hairless plaque over scalp since birth which gradually progressed to become a warty lesion over the past $10-12$ years. Since past 2 years, patient complaint of itching, oozing and bleeding from the lesion even after a trivial insult. Physical 
examination of the lesion revealed a $4 \times 3 \mathrm{~cm}$ yellow-brown, waxy, verrucous plaque with nodulo-ulcerative growth on its surface measuring $1.5 \times 1 \mathrm{~cm}$ (Fig.1). Lesion was painless, non indurated and there was no regional lymphadenopathy. Complete excision of the lesion under local anaesthesia was done with a normal 1 $\mathrm{cm}$ margin around the lesion and was sent for histopathological examination.

Histopathological examination revealed epidermis with papillomatosis, with several cystic invaginations into the dermis (Fig. 2A). These invaginations showed many papillae lined by two layers of epithelial cells: the luminal layer composed of columnar epithelial cells, with signs of decapitation secretion and the outer layer made up of cuboidal cells (Fig.2B). Underlying fibrovascular stroma showed moderate lymphoplasmacytic inflammatory infiltrate. The histopathological features were diagnostic of syringocystadenoma papilliferum.

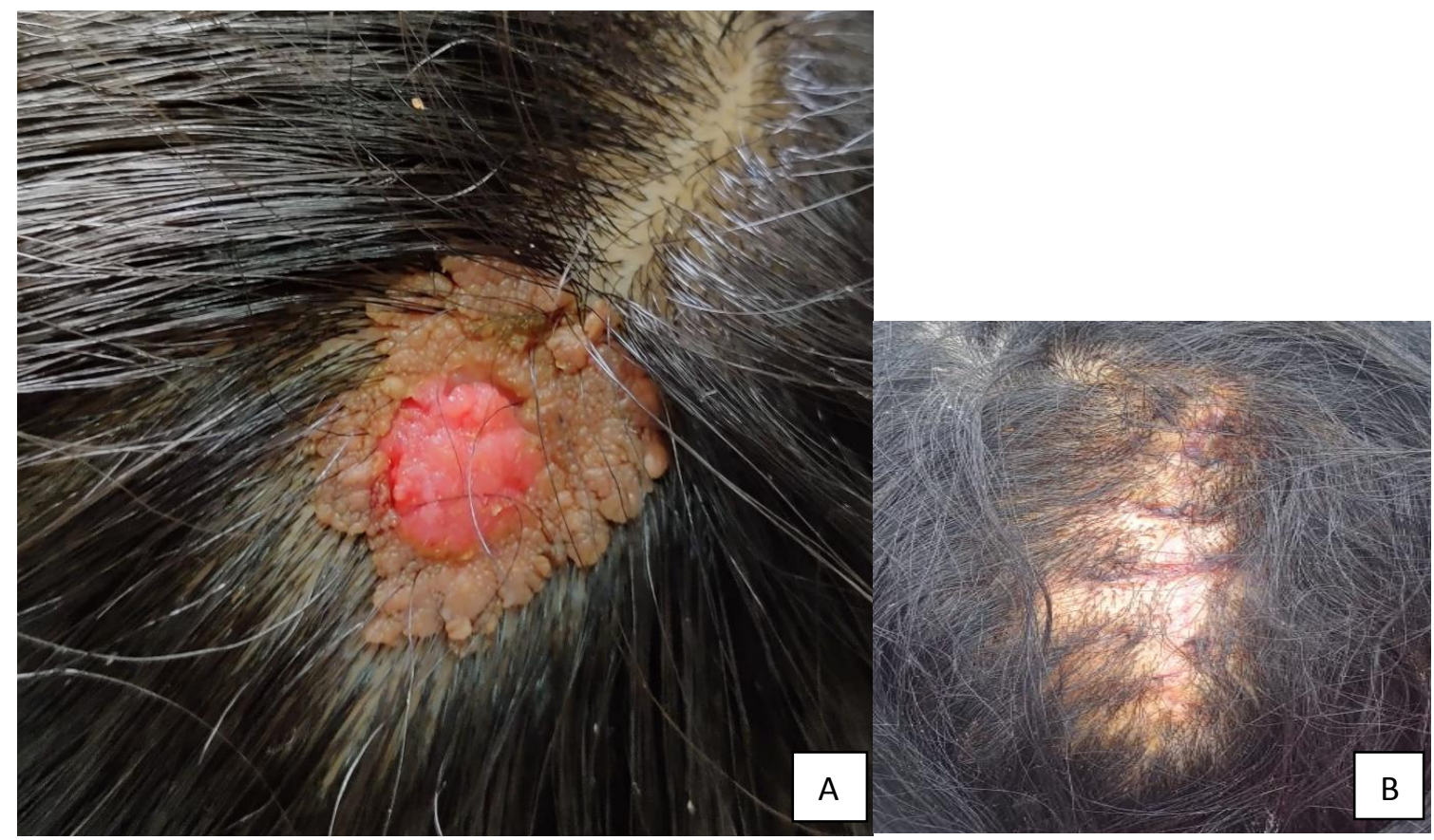

Figure 1: A) A yellow-brown, waxy, verrucous plaque present since birth on scalp with nodulo- ulcerative growth on its surface; B) Post-excision
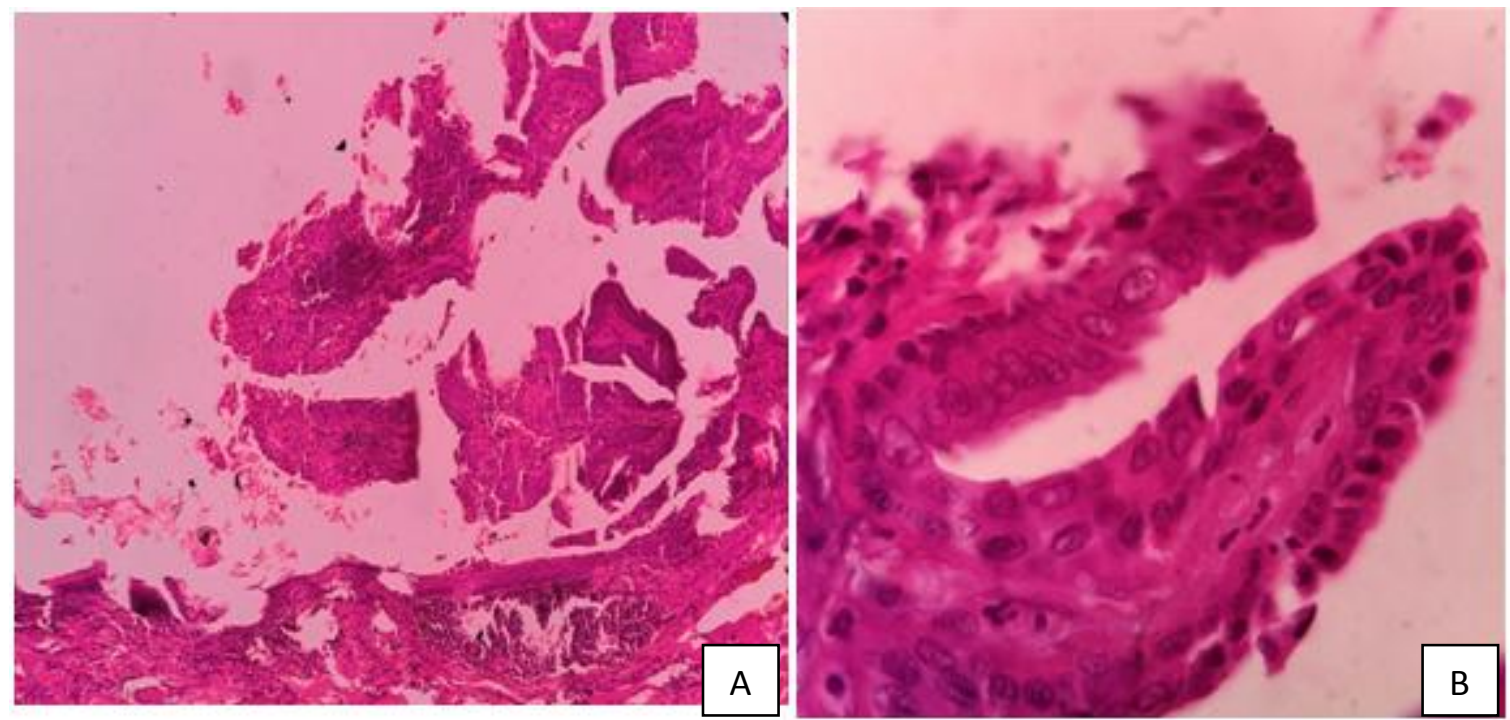

Figure 2: A) H\&E showing papillary fronds arising from the epidermis lined by multilayered epithelium $(100 X)$; B) Papillae lined by double layer of columnar to cuboidal epithelium. 


\section{Discussion}

Nevus sebaceous has the potential to generate different lineages of tumors that are not restricted to the sebaceous lineage. ${ }^{3,4}$ Multiple tumours of adnexal origin (such as trichoblastomas, apocrine adenomas, sebaceoma, hidradenoma papilliferum, trichilemmoma etc.) have been reported to arise on sebaceous nevus, among which one is Syringocystadenoma papilliferum. ${ }^{5}$ The nodular variety has its predilection for the trunk, but in our case it presented on the scalp. Thus, emphasizing on the importance of knowing the various presentations of syringocystadenoma papilliferum and also the knowledge of various tumors that arise on nevus sebaceous. In our case, basal cell carcinoma and pyogenic granuloma were considered as the differential diagnoses. However, slowly growing fleshy plaque that sometimes oozes fluid and sometimes bleeds, present over a background of nevus sebaceous is characteristic for SP. Syringocystadenocarcinoma papilliferum, a malignant counterpart of SP, should be ruled out when evaluating the histopathology of SP. ${ }^{6,7}$ Thus, prophylactic surgical excision remains the treatment of choice. However, recurrence is common. $^{7}$

\section{Conclusion}

Syringocystadenoma papilliferum is an uncommon sweat gland tumor with variable clinical presentations. Here, we report a case of nodular syringocystadenoma papilliferum that developed on nevus sebaceous (present since birth). The nodular variety has the predilection for the trunk, but in our case it presented on the scalp. Thus, the awareness of various presentations of SP and the various tumors that may arise in association with nevus sebaceous can prevent misdiagnoses and overtreatment. Due to the risk of a malignant change, a prophylactic surgical excision, followed by a detailed histopathologic examination is the treatment of choice.
Financial Support and Sponsorship: Nil.

Conflicts of Interest: There are no conflicts of interest.

\section{Bibliography}

1. Kantrow SM, Ivan D, Williams MD, Prieto VG, Lazar AJ. Metastasizing adenocarcinoma and multiple neoplastic proliferations arising in a nevus sebaceus. Am J Dermatopathol2007;29:462-6.

2. Karg E, Koram I, Varga E, Ban G, Turi S. Congenital syringocystadenoma papilliferum. Pediatrics Dermatol. 2008; 25: 132-33.

3. Idriss $\mathrm{MH}$, Elston DM: Secondary neoplasms associated with nevus sebaceous of Jadassohn: a study of 707 cases. J Am AcadDermatol2014;70:332337.

4. Cribier B, Scrivener Y, Grosshans E: Tumors arising in nevus sebaceous: a study of 596 cases. J Am Acad Dermatol2000;42:263-268.

5. Stavrianeas NG, Katoulis AC, Stratigeas NP. Development of multiple tumours in a sebaceous nevus of Jadassohn. Dermatology. 1997; 195: 155-58

6. Parekh V, Guerrero CE, Knapp CF, Elmets CA, McKay KM. A histological snapshot of hypothetical multistep progression from nevus sebaceus to invasive syringocystadenocarcinoma papilliferum. Am J Dermatopathol. 2016 Jan;38(1):5662.

7. Ishida-Yamamoto A, Sato K, Wada $T$. Syringocystadenoma papilliferum: A case report and immunohistochemical comparison with its benign counterpart. J Am Acad Dermato. 2001; 45: 755-59. 